\title{
Non-circulating equity and excessive equity financing
}

(C) Higher Education Press and Springer-Verlag 2007

\begin{abstract}
In the Chinese stock market, the price of exchangeable stock is determined by the discounted future uncertain cash flow, while the price of non-circulating stock depends on per book value. In general, because investors holding non-circulating equity maintain the control power, corporate finance and investment decisions reflect their interests. The pricing mechanism of noncirculating stock violates the basic pricing principle of the capital market. Therefore, corporate finance decisions deviate from the NPV (net present value). As a result, excessive equity financing problems would occur in the listed companies.
\end{abstract}

Keywords non-circulating equity, excessive equity financing, net present value, Chinese stock market

摘要 中国股市中，流通股的价格取决于公司未来不确定现金流期望值的折 现; 非流通股的价格则依据每股净资产来制订。通常非流通股股东拥有公司的控 制权, 因此公司的投融资决策体现了非流通股股东的利益。非流通股的定价制度

Translated from Shijie Jingji Wenyuan 世界经济文源 (World Economic Forum), 2004, (4): $41-50$

ZHENG Zuxuan $(\bowtie)$

Room 2-101, Building 18, Renhe Quarter, Kaifeng 475001, China

E-mail:021015059@fudan.edu.cn

ZHOU Ye, LI Da

Guanghua Management School, Peking University, Beijing 100871, China

ZHAO Tao

Henan University, Kaifeng 475001, China 
有违资本市场对资产定价的基本原理, 所以公司的投融资决策也偏离了公司财务 理论所确定的净现值标准，导致上市公司存在过度股权融资问题。

关键词 非流通股, 过度股权融资, 净现值, 中国股市

\section{Introduction}

Researches on financing decisions of the listed companies are centered on how to make the optimal investment decision by the shareholders, i.e. whether the cash flow incurred by their decision brings along the maximized profit. In terms of evaluating the profitability of a particular investment, the cost of capital is of vital importance; hence, the shareholders should choose an appropriate issue method. Starting from this point, some western researchers have tried to look into corporate issue decisions from various angles, e.g. Modigliani and Miller (1958) have studied the relationship between issue decision-making and the corporate value; Jenson and Meckling (1976) analyzed this problem from the perspective of sharing of agency costs between shareholders and managers; Myers and Majiluf (1984) have, on the basis of the asymmetric information theory, studied the state of operation signal which is in light of the company's issue activity and made the Pecking Order Hypothesis; James and Lewis (1986) and Titman (1984) have analyzed the relationship among the issue decision-making, the product market competition strategy, and characteristics of the input or output; Harris and Raviv (1988), Stulz (1988) and Israel (1991) have studied how managers try to influence the control power through the financing decision-making; Singh and Hamid (1992) and other researchers have focused on the impact of the market orientation and financial freedom process in the developing countries on the financing decision-making.

Studies on equity financing of Chinese listed companies take the optimal capital structure theory as the starting point, which can roughly be divided into two lines of issue preference and over issue, other than the focus on the output/ input market by Bai and Li (2000) and Liu et al. (2003). Moreover, most of the studies followed the track of comparing the costs of equity issue and credit issue, trying to explain the existence of equity issue preference or not, as with Huang and Zhang (2001), Shen and Tian (1999), Chen and Shan (1999), Pei (2000), Wan et al. (2002), Zheng et al. (2001), Tan and Wu (2002) and others. As for the perspective of non-circulating equity shareholders, Huang and Song (2002) have pointed out that the major shareholders of non-circulating equity in China may get profits if they can make new issue or divide the stock at a price higher than that of the per book value; therefore, the asymmetric information factor as illustrated by Myers turned out to be of secondary importance while the cost of agency between the investors holding exchangeable equity and those holding 
non-circulating equity. Li et al. (2000) have pointed out the conflict of interest between the shareholders of non-circulating equity and those of exchangeable equity. $\mathrm{Wu}(2003)$ has discussed whether the investors of non-circulating investors after peeling off the bad assets would choose to make profits from the performance of the listed companies through a proper supervision strategy, or from the shareholders of exchangeable equity through an infringement strategy.

The above literature review shows that, due to hardly any coverage from the overseas scholars or lack of systematic analysis with the domestic scholars, it calls for further study on the financing features of the listed companies in China, taking account of such a special establishment as the non-circulating equity investors. The corporate finance theory sets net present value (NPV) as the criteria for investment decision-making in an efficient market. This paper tries to demonstrate that (1) because there are different pricing mechanisms for the exchangeable and non-circulating equities, the management standing for the interest of the investors of the non-circulating equity may proceed with investment even if in the face of a non-positive NPV project, hence the resources are improperly allocated, i.e. over equity issuing incurred; (2) before the exchangeability of the non-circulating equity is settled, the restrictive policy established by China Securities Regulatory Commission (CSRC) might only alleviate the harm of over equity issuing but not redress the deviation effectively.

\section{Model for over equity issuing}

\subsection{Introduction to the model}

2.1.1 The investors of the exchangeable and non-circulating equities vary in their interests while the former pay attention to the market price and the latter to per book value.

In line with the present policies, except for the five total circulating shares ${ }^{1}$, the rest of the listed companies in China are not allowed to trade at the secondary market, but limited to such trading methods as transfer and auction. The difference in negotiability seriously affects the market value of the control power; therefore, the transfer price of the non-circulating equity depends upon per book value. The analysis of the state share gross sample shows that the median ratio of transfer price to per book value is just 1.07 , the premium is $7 \%$, and the median ratio of the transfer price to the exchangeable equity market price is $17.5 \%{ }^{2}$. This tells that the investors of the non-circulating equity try to maximize the book value; while the investors of the exchangeable equity try to maximize the market value. The different pricing methods resulted from the special institution of Chinese 
stock market are the root causes for the disagreement of interests between the investors of the non-circulating equity and those of the exchangeable equity.

2.1.2 The issue policy is determined by the non-circulating equity of control power

The ownership structure of Chinese stock market is featured by high concentration of non-circulating equity, hence the absolute control power of the non-circulating equity holders (see Table 1).

Table 1 Percentage of the non-circulating equity in total Chinese shares (1997-2003)

\begin{tabular}{llllllll}
\hline Year & 1997 & 1998 & 1999 & 2000 & 2001 & 2002 & $2003^{\text {a) }}$ \\
\hline $\begin{array}{l}\text { Percentage of the non-circulating } \\
\text { equity in total shares (\%) }\end{array}$ & 68.34 & 68.41 & 65.05 & 64.28 & 65.25 & 65.34 & 64.57 \\
\hline
\end{tabular}

a) These data are based on the total 1,220 A shares of both Shanghai and Shenzhen Stock Exchanges on July 28, 2003.

Source: The authors counted by means of the TX investment analysis system V3.10.

Moreover, the simple moving average number of shareholders for the total 1,220 A shares of both Shanghai and Shenzhen Stock Exchanges on July 28, 2003 is 52,193, among which around ten are the non-circulating shareholders, the rest are the exchangeable shareholders, and the shareholding structure centers on the non-circulating shareholders. The non-circulating equity holders, though small in number but strong in share-holding, can control the Board of Directors and the Shareholders Meeting. Therefore, the issuing policy in Chinese listed companies is decided by the controlling investors of the non-circulating equity.

The corporate finance theory sets NPV as the investment decision criteria in an efficient market. A company will not finance its investment through the capital market until the NPV, which has the cost of issuing deducted, is larger than zero and its own funds are insufficient for the investment project. However, the existing pricing difference between the exchangeable and non-circulating equity will cause the non-circulating equity holders, for their own interests, still finance by means of equity issue even if in the case that NPV is not positive.

\subsection{Conditions for issue}

In order to better illustrate that over issuing is motivated by different pricing mechanisms, we assume that

(a) the capital market is complete and efficient, and there is no transaction cost for equity issue; 
(b) the company has already been listed, hence the initial public offering (IPO) factor does not exist;

(c) the company's market value is the conditional expectancy for its future value on the basis of the existing information without the discount factor representing the time value;

(d) the company now holds zero flowing cash, and it only finances by means of equity issue;

(e) the exchangeable equity holders are outsiders without the actual control power; while the non-circulating equity holders are insiders with the actual control.

The time of $t=0,1,2$ only signifies the sequence of decision making but not any disclosure of new information. In this sense, the shareholders have the same expectancy towards the future cash flow (see Fig. 1).

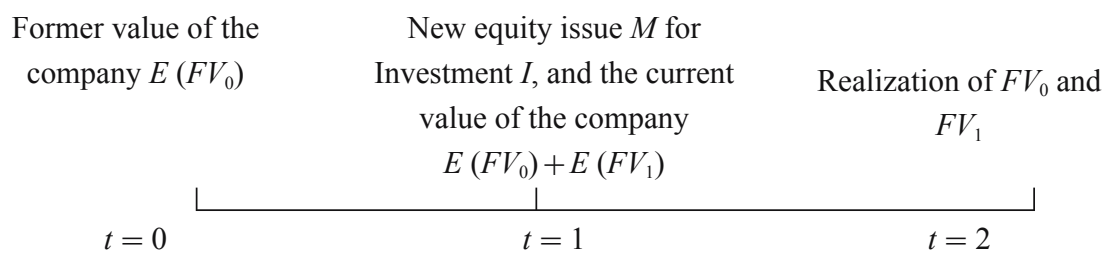

Fig. 1 Timetable for the model

If the listed companies can make uncertain amount of cash flow $F V_{0}$ at $t=2$ out of the existing assets at $t=0$, and its market value at $t=0$ is the discount of the uncertain cash flow $F V_{0}$ at $t=0$; if the company's total share at $t=0$ is 1 , among which the percentage of the non-circulating equity to the total amount of share is assumed as $a$, and the non-circulating equity holders take control of the company; then, the percentage of the exchangeable equity to the total amount of shares is $(1-a)$, and the holders all belong to the outsiders without actual control over the company. The issued debt of the company is assumed as $D$, its net assets as $A_{0}$, and the equity value of the company at $t=0$ as $V_{1}^{\text {old }}$. If the agreed transfer price set by the non-circulating equity holders is $b$ times of the company's per book value, and there is an investment project occurred stochastically at $t=1$, which will produce an uncertain amount of cash flow $\mathrm{F} V_{1}$ at $t=2$. The project requires investment $I$, i.e. if the company wants to invest in this project, it needs to finance through the stock market accounting for $I$. The company has to make out the finance decision and implement it at $t=1$, otherwise, the project disappears at $t=1$. Both the inside and outside investors of the company hold the same evaluation towards the project. $V_{1}^{\text {old }}$ refers to the market value at $t=1$ of the 
shares the investors have already held at $t=0$. At $t=2$, the company realizes $F \mathrm{~V}_{0}$ and $F V_{1}$.

Two cases are taken into account, i.e. public offering and right offering.

\subsubsection{Public offering}

At $t=0$, if this is an efficient capital market, the share price reflects the claim on the company's uncertain cash flow, hence the equation as below

$$
V_{0}^{\text {old }}+D=E\left(F V_{0}\right)
$$

The market value of the exchangeable equity is

$$
(1-a) V_{0}^{\text {old }}=(1-a)\left[E\left(F V_{0}\right)-D\right]
$$

The market value of the non-circulating equity is

$$
a V_{0}^{\text {old }}=a\left[E\left(F V_{0}\right)-D\right]
$$

At $t=1$, new investment project requires the sum of $I$, which all comes from the public offering, therefore $M=I$, then the net assets of the company at $t=1$ is

$$
A_{1}=A_{0}+M
$$

Since we assume this is an efficient market without asymmetric information, the market value of the company's total shares at $t=1$ is

$$
V_{1}^{\text {old }}=E\left(F V_{0}\right)-D+\left[E\left(F V_{1}\right)-M\right]=V_{0}^{\text {old }}+N P V
$$

Scilicet

$$
V_{1}^{\text {old }}=\frac{V_{1}^{\text {old }}}{V_{1}^{\text {old }}+M}\left[E\left(F V_{0}\right)+E\left(F V_{1}\right)-D\right]
$$

According to Eq. (5), at $t=1$, the market value of the old shares equals to their market value at $t=0$ plus the NPV of the new project. It is clear that if the NPV is negative, public offering will do harm to the benefits of the former shareholders.

According to Eq. (6), the ratio of the non-circulating equity to the total shares is $a \frac{V_{1}^{\text {old }}}{V_{1}^{\text {old }}+M}$. 
The transaction value for the exchangeable equity is based on the market value, which follows the principle that the exchangeable stock price is determined by the discount of the future uncertain cash flows; the transaction value for the non-circulating equity is based on the book value, which follows the principle that the non-circulating stock price depends on per book value. The price discrepancy between the exchangeable and non-circulating equity can be understood as the transaction cost for prohibiting the non-circulating equity from trading on the secondary market. This "dual system" of pricing results in the distinctive difference between the market value and actual transaction price for the non-circulating shares of the old holders at $t=1$.

In light of the abovementioned pricing mechanism, the curb exchange value for the shares of the non-circulating equity holders at $t=0$ shall be $a b A_{0}$; and at $t=1$ shall be $a \frac{V_{1}^{\text {old }}}{V_{1}^{\text {old }}+M} b A_{1}$. The public offering decision is dependent on the impact on the non-circulating equity holders who have the actual control over the company. If there is no public offering, the curb exchange value for the shares of the non-circulating equity holders is $a b A_{0}$; if there is public offering, $a \frac{V_{1}^{\text {old }}}{V_{1}^{\text {old }}+M} b A_{1}$. To put it in detail, the condition for public offering is as below

$$
a \frac{V_{1}^{\text {old }}}{V_{1}^{\text {old }}+M} b A_{1} \geqslant a b A_{0}
$$

Namely

$$
\frac{V^{\text {old }}}{V_{1}^{\text {old }}+M} A_{1} \geqslant A_{0}
$$

From Eqs. (4) and (8), we can get the final condition for public offering is

$$
V_{1}^{\text {old }} \geqslant A_{0}
$$

The condition as Eq. (9) means that, as long as the market value of the shares of the old shareholders at $t=1$ after the right offering is larger than the net assets at $t=0$, right offering will be favorable to the non-circulating equity holders no matter how large the NPV is, hence the company always tends to issue new shares. This result is because of the different pricing mechanisms between the exchangeable and non-circulating equities but the same claim on the future uncertain amount of cash flow between the two groups of shareholders.

According to Eqs. (5) and (9), the condition for public offering can be converted into as below

$$
N P V \geqslant A_{0}-V_{0}^{\text {old }}
$$


In another word, as long as the net assets of the project are larger than the margin that the net assets deduct the market value of the company's equity, public offering will be favorable to the non-circulating equity holders who have actual control over the company. Generally speaking, the net assets are less than the equity's market value, therefore, the condition for public offering as Eq. (10) shows that even if the NPV of the new project is below zero, public offering still is a case of benefit for the non-circulating equity holders.

\subsubsection{Right offering}

The difference between right offering and public offering only lies in the old shareholders. In the case of right offering, the holders of the non-circulating equity normally disclaim the right. Therefore, the right offering only targets at the holders of the exchangeable equity. Moreover, the right offering for the exchangeable equity holders shall not turn into profits, otherwise, an arbitrage may be incurred, which violates the Efficient Capital Market Hypothesis. The market value of the old shares at $t=1$ can be represented by Eq. (5) as well. Similarly, the portion of the non-circulation equity to the total shares can still be represented as $a \frac{V_{1}^{\text {old }}}{V_{1}^{\text {old }}+M}$. Therefore, as for the non-circulation shareholders, the conditions of public offering and right offering are the same. Even if we get a looser assumption not to require the non-circulation shareholders to waiver the right in right offering, the result as above will not be affected. The reason is that right offering can bring the shareholders zero profit. Even if the non-circulation shareholders hold some exchangeable shares through right offering, the newly held shares still are equal to the sum paid, and the portion of the non-circulation equity to the total shares remains $a \frac{V_{1}^{\text {old }}}{V_{1}^{\text {old }}+M}$. The analysis of right offering shows that the conditions for right offering will not change as illustrated by Eq. (10) whether or not the non-circulation shareholders execute the right in the right offering.

Therefore, in a completely effective capital market where the non-circulation shares whose holders have the actual control over the company can not exchange on the secondary market, as long as $N P V \geqslant A_{0}-V_{0}^{\text {old }}$, the company may need to finance through equity issue either by public offering or right offering. The above analysis over public offering and right offering shows that even if an investment project will not produce positive NPV, the non-circulation shareholders, based on their own interests, still may decide to invest, hence constituting over equity issue. 


\subsubsection{Optimal scale of issue}

As assumed above, the available projects for investment emerge stochastically; therefore, the scale of issue is determined by the project itself without an optimal scale of issue. This assumption is rational as for a project of positive NPV. However, taking into consideration the case that the companies may invest in risk-free assets, projects of any scale of investment are in fact available. In the case of risk-free assets, the investment, deducted by the charge of issue, always has a negative NPV. Then the optimal scale of issue problem emerges.

From Eq. (7), we can get the returns Ri the non-circulation shareholders yield through the equity issue shall be

$$
R_{i}=a b \frac{V_{1}^{\text {old }} A_{1}}{V_{1}^{\text {old }}+M}-a b A_{0}=\frac{a b M\left(V_{1}^{\text {old }}-A_{0}\right)}{V_{1}^{\text {old }}+M}
$$

Substitute Eq. (5) into Eq. (11) and we can get

$$
R_{i}=\frac{a b M\left[E\left(F V_{0}\right)+E\left(F V_{1}\right)-D-A_{0}-M\right]}{E\left(F V_{0}\right)+E\left(F V_{1}\right)-D}
$$

Hence, the optimized returns of the non-circulation shareholders through public offering will be

$$
\max _{M, E\left(F V_{1}\right)} \frac{a b M\left[E\left(F V_{0}\right)+E\left(F V_{1}\right)-D-A_{0}-M\right]}{E\left(F V_{0}\right)+E\left(F V_{1}\right)-D}
$$

The risk-free assets mean that

$$
\begin{array}{ll}
E\left(F V_{1}\right)=M-C & \text { when } M>0 \\
E\left(F V_{1}\right)=C=0 & \text { when } M=0
\end{array}
$$

Among which, $C$ refers to the cost of issue, which is a fixed cost. In light of the condition for issue, i.e. $N P V \geqslant A_{0}-V_{0}^{\text {old }}$, we can get

$$
E\left(F V_{1}\right)-M \geqslant A_{0}-\left[E\left(F V_{0}\right)-D\right]
$$

From Eqs. (14) and (15), we know that, when $C>E\left(F V_{0}\right)-D-A_{0}$, the condition of issue as in Eq. (15) shall not be satisfied; while $C \leqslant E\left(F V_{0}\right)-D-A_{0}$, the condition of issue as in Eq. (15) can be satisfied. This optimization can be expressed as

$$
\max _{M, E\left(F V_{1}\right)} \frac{a b M\left[E\left(F V_{0}\right)+E\left(F V_{1}\right)-D-A_{0}-M\right]}{E\left(F V_{0}\right)+E\left(F V_{1}\right)-D}
$$




$$
\begin{array}{ll}
\text { s.t. } & E\left(F V_{1}\right)=M-C \\
& E\left(F V_{1}\right) \geqslant 0 \\
& M \geqslant 0
\end{array}
$$

If the case of $M=0, E\left(F V_{1}\right)=0$ is overlooked, the solution is

$$
\begin{gathered}
M^{*}=E\left(F V_{0}\right)-D-A_{0}-C \\
E^{*}\left(F V_{1}\right)=E\left(F V_{0}\right)-D-A_{0}
\end{gathered}
$$

At the optimal size of issue

$$
V_{1}^{\text {old }}=E\left(F V_{0}\right)-D-C
$$

Then, the net assets are

$$
A_{1}^{\text {old }}=E\left(F V_{0}\right)-D-C
$$

Therefore, the share price equals to the net assets at the optimal size of issue.

\section{Practical significance of the model}

As the above-mentioned model has shown, in the case that the state shares are not allowed to exchange, the equilibrium of the over equity issue will be the case when the share price equals to the net assets, i.e. $\mathrm{PB}^{1}$ is 1 . However, Table 2 shows that the PB of the A Share market in China does not approach 1, while exceeds 1 with a big margin. The authors hold the fundamental cause is the restrictive policies over equity issued by CSRC.

China Securities Regulatory Commission has stipulated policies to restrict the public offering and right offering in order to curb the over equity issuing. The policies to control public offering ${ }^{2}$ require that the weighted average yield of net assets of the latest three fiscal years shall not be lower than $10 \%$, and the weighted average yield of net assets shall not be lower than 10\%; if the amount of public offering exceeds $20 \%$ of the total shares, the proposal shall be passed with over half voting rights of the exchangeable (social public) shareholders present the Shareholders Meeting. The binding policies over right offering ${ }^{3}$ require that only

\footnotetext{
${ }^{1} \mathrm{~PB}$, or $\mathrm{P} / \mathrm{B}$, refers to price /book value.

${ }^{2}$ Source: CSRC, "Notification of Improved Codes for Public Offering (Draft for Suggestion)", June 21, 2002, website of CSRC.

${ }^{3}$ Source: Dept. of Public Offering, CSRC, "Memo of Public Offering Examination: No. 5", May 10, 2002, website of CSRC.
} 
Table 2 PB in Chinese security market

\begin{tabular}{lcc}
\hline Year & PB of A Share (simple average) & PB of B Share (simple average) \\
\hline 1992 & 8.76 & 2.79 \\
1993 & 4.40 & 2.34 \\
1994 & 2.80 & 1.22 \\
1995 & 2.36 & 0.96 \\
1996 & 4.11 & 1.63 \\
1997 & 4.69 & 1.06 \\
1998 & 4.56 & 0.57 \\
1999 & 5.25 & 0.88 \\
2000 & 16.76 & 5.32 \\
2001 & 6.59 & 4.73 \\
2002 & 4.80 & 2.92 \\
$2003^{\text {a) }}$ & 3.73 & 2.82 \\
\hline
\end{tabular}

a) Data for the year of 2003 are those for August 12, 2003, while those for other years are data for the end of the respective year.

Source: The authors counted by means of the TX investment analysis system V3.10.

those with no less than $6 \%$ of the weighted average yield of net assets of the latest three fiscal years are qualified to issue right offering, and the amount of right offering shall not exceed $30 \%$ of the existing shares.

The authors believe that for A Share market, it is these restrictive policies over equity issue that have prevented the major shareholders from issuing at the optimal scale, so as to avoid the share prices dropping to the level of the net assets. The problem is if the exchangeable shareholders have correctly foreseen this mechanism, they will degrade the evaluation of the equity they hold. In turn, the institutional arrangement to restrict non-circulation equity trade will influence the values of the non-circulation shares and the exchangeable shares as well. The market pricing system therefore will be totally damaged because the prices of the exchangeable shares in this case can not accurately reflect the claim on the uncertain cash flows in the future.

Data in Table 2 tell us that for a long time before the year of 2000, prices of the great majority of B Shares are close to or lower than the net assets of each share, while those of A Shares much greater than the net assets. The A Share market has long been the pool of individual investors; and the B Share market of foreign institutional investors before the year of 2000, and of a mass of individual investors ever since mid-2000 when the market was allowed to open to the domestic investors. As stated above, the non-circulation shareholders may damage the benefits of the exchangeable shareholders through re-issue. Assume that the institutional investors can more accurately forecast this mechanism than the individual investors, which can be verified by the difference of $\mathrm{PB}$ as listed in Table 3. 
Table 3 B Share market public offering and right offering capital data (Jan. 1, 1997-Sep. 9, 2003)

\begin{tabular}{lcccccc}
\hline & Code & Type & $\begin{array}{c}\text { Method of } \\
\text { issue }\end{array}$ & $\begin{array}{c}\text { Date of } \\
\text { issue }\end{array}$ & $\begin{array}{c}\text { Offer } \\
\text { price }\end{array}$ & $\begin{array}{c}\text { Volume } \\
\text { (shares) }\end{array}$ \\
\hline JMC B & 200550 & Public offering & $\begin{array}{c}\text { Private } \\
\text { placement }\end{array}$ & $1998-10-30$ & 2.81 & $170,000,000$ \\
$\begin{array}{c}\text { Shenzhen } \\
\text { Hwafa B }\end{array}$ & 200020 & Right offering & $\begin{array}{c}\text { Proportional } \\
\text { placement }\end{array}$ & $1997-11-6$ & 3.74 & $9,555,000$ \\
Fiyta B & 200026 & Right offering & $\begin{array}{c}\text { Proportional } \\
\text { placement }\end{array}$ & $1997-11-6$ & 7.47 & $6,480,000$ \\
Jin Qiao B & 900911 & Right offering & $\begin{array}{c}\text { Proportional } \\
\text { placement }\end{array}$ & $1997-8-4$ & 4.43 & $42,900,000$ \\
Shenzhen & 200012 & Right offering & $\begin{array}{c}\text { Proportional } \\
\text { placement }\end{array}$ & $1997-7-31$ & 3.73 & $43,343,889$ \\
$\begin{array}{c}\text { Livzon B } \\
\text { Hai Xin B }\end{array}$ & 200513 & Right offering & $\begin{array}{c}\text { Proportional } \\
\text { placement }\end{array}$ & $1997-7-21$ & 4.39 & $19,199,400$ \\
Vanke B & 200002 & Right offering & $\begin{array}{c}\text { Rroportional } \\
\text { placement } \\
\text { placement }\end{array}$ & $1997-7-17$ & 4.2 & $19,278,825$ \\
Da Ying B & 900921 & Right offering & $\begin{array}{c}\text { Proportional } \\
\text { placement }\end{array}$ & $1997-7-17$ & 2.95 & $13,604,500$ \\
\hline
\end{tabular}

Source: the authors have worked out the table based on bulletins concerned.

The conditions of issue for the non-circulation shareholders as in Eq. (10) show that, if $\mathrm{PB}=1$, and $A_{0}=V_{0}^{\text {old }}$, then the conditions of issue as $N P V \geqslant A_{0}-V_{0}^{\text {old }}$ can turn into $N P V \geqslant 0$, which matches the criterion of NPV for investment, i.e. unless the new project can bring about positive benefits shall this investment or equity issue be meaningful. This can help explain why PB of B Share market has been lingering about 1 before the year of 2000. It is the comparatively low level of PB of B Share market that has incurred the difficult position of B Share listed companies in face of equity issue. Table 3 shows that from the years of 1998 and 1999 when PB of B Share market were below 1 successively to September, 2003, B Share market has been in the state of stagnation in terms of equity issue, or it has lost the function of equity issue during this period.

\section{Analysis on the restrictive policy of equity issue}

\subsection{Root causes behind the policy}

Market competition will make it hard to get an investment project of positive NPV but it is easy to get one of non-positive NPV. As for the holders of the 
non-circulating equity, investment projects in line with Eq. (10) are available everywhere, for instance, an investment in a risk-free asset. Therefore, as long as the pricing difference exists between the non-circulating and the exchangeable equities, the urge for equity issue of the non-circulating equity holders shall not be easily quieted down.

If the investment of a listed company always goes to an unprofitable project, its performance will be downgraded till the equity shares equal to the net assets. Therefore, because the non-circulation equity holders have the actual control over the company, the average price of shares in Chinese stock market would drop to the level of net assets in a short run if CSRC had not issued the restrictive policies, which prevent the over issue from prevailing. The point to note is that these policies only stretch the negative effects of the over issue to a longer run.

\subsection{Limitations of the restrictive policies}

These restrictive policies over the issue can be put into two categories, namely, the restriction over qualifications of issue and that over the amount of issue. The root cause of the over issue, however, lies in the fact that the investment goes to projects of negative NPV. It is clear that such restrictive polices have not hit the investment opportunities the listed companies face, hence unable to effectively prevent the companies from such behavior.

The restrictive polices over qualifications of issue require the past investments of the companies have born favorable value, which is unable to guarantee the future investments are of value. Meanwhile, as for those companies of non-excellent performance, they may be prohibited from financing through equity issue even if a project of good potential profitability is available due to the above mentioned restrictive policies. If there are no other channels for financing or enough floating cash, the investment opportunity will be missed.

However, the restrictive polices over qualifications of issue have their positive functions as well. In the long run, such policies can encourage the companies to invest in the projects of favorable profitability, which may make the companies smoothly get access to the qualifications for issue. As for a company concerned with its long-term interest, it is a necessary choice to avoid profitless projects. Whether the non-circulation shareholders who have the control over the company are concerned with the long-term or short-term interest, it is dependent upon their expectations upon the future possibilities of investment and the discount of the long-term interest.

The restrictive polices over the amount of issue can directly limit the scale of issue, which in effect may reduce the harm of over issue if the invested project is no profitability. However, such polices at the same time may limit the strength of financing through the stock market. If there is a profitable investment available 
but the company lacks much of the fund, such restrictive polices then will result in the loss of the investment possibility.

Among others, this policy is fairly significant that "if the amount of public offering exceeds the total shares of the company by $20 \%$, the proposal shall not be approved until over half of the voting rights with the exchangeable shareholders (public shares) present at the Shareholders Meeting have agreed." The significance of this policy comes from its protection of the interests of the exchangeable shareholders; therefore, the non-circulation shareholders of controlling power would not carry out large scale investment or financing in a project of negative NPV, hence avoid the harm to the exchangeable shareholders.

The fundamental solution to shunning such a conflict is the abolishment of the non-circulation restriction over the non-circulation equity, hence clearing up the fundamental cause to the over issue problem. Only through this method can the companies be pushed back to the criteria of positive NPV in terms of investment and financing.

Acknowledgements This paper is based on a research sponsored by the Chinese Securities Association in 2003. Preliminary results were presented at the Adam Smith Forum of Nanjing University in Oct. 2003 and the Third Chinese Economics Annual Conference in Dec. 2003. The authors would like to extend their gratitude to the precious remarks offered by those present at the above-mentioned two conferences.

\section{References}

Bai Chong-en, Li Shan (2000). Capital structure and product market strategy. Annals of Economics and Finance, (1): 383-402

Chen Xiao, Shan Xin (1999). Does debt financing increase the cost of capital of listed company? Economic Research Journal, (9): 13-17

Harris M, Raviv A (1988). Control contests and capital structure. Journal of Financial Economics, (20): 55-86

Huang Haigui, Song Min (2002). Capital Structure of Chinese Listed Companies. Shanghai: Fudan University Press

Huang Shao'an, Zhang Gang (2001). Analysis of equity issue preference of Chinese listed companies. Economic Research Journal, (11)

Israel R (1991). Capital structure and the market for corporate control: The defensive role of debt financing. Journal of Finance, (46): 1391-1409

James B, Lewis T (1986). Oligopoly and financial structure: The limited liability effect. American Economic Review, (76): 956-970

Jenson M C, Meckling W H (1976). Theory of the firm: Manager behavior, agency costs and ownership structure. Journal of Financial Economics, 3(4): 305-60

Li Leixun, Xu Lingfeng, Lin Bin, Yu Yang, Cao Yongzhi, Zheng Xuezhang, Zhang Wenxian (2000). Re-issue and Supervision of the Listed Companies. Report of the First Stage Study for the Joint Research Project with Shanghai Securities

Liu Zhibiao, Jiang Fuxiu, Lu er'po (2003). Capital structure and product market competitiveness. Economic Research Journal, (7): 60-67 
Modigliani F, Miller M H (1958). The cost of capital, corporation finance and the theory of investment. The American Economic Review, (48): 261-297

Myers S C, Majiluf N S (1984). Corporate financing and investment decision when firms have information that investors do not have. Journal of Financial Economics, (13): 187-221

Pei Ping (2000). Equity Issue of Chinese Listed Companies. Nanjing: Nanjing University Press

Shen Yifeng, Tian Jing (1999). The quantidty research on the cost of capital of chinese listed companies. Economic Research Journal, (11): 62-68

Singh A, Hamid J (1992). Corporate Financial Structures in Developing Countries. International Finance Corporation Technical Paper. No.1 IFC, Washington, DC

Stulz R (1988). Managerial control of voting rights: Financing policies and the market for corporate control. Journal of Financial Economics, (20): 25-54

Tan Jun, Wu Linxiang (2002). The empirical analysis of the public offering effect. Shanghai securities news, Sep. 16th

Wan Chaoling, Chu Chengzhong, Li Xiang, Yuan Ye, Zhou Jianxin (2002). Study on outside capital sources for listed companies: An empirical study on their capital structure and financing cost. Report of the Third Stage Study for the Joint Research Project with Shanghai Securities

Wu Shukun (2003). Economic analysis of the majority shareholder's behaviors. Chinese Securities Study, (2): 22-32

Zheng Jianghuai, He Xuqiang, Wang Hua (2001). Financial constraints in the listed companies investment: Explanation from the views of structure of equity. Journal of Financial Research, 257(11): 92-99 